\title{
Interview with Chris Tilly
}

\section{ROBERTO VÉRAS DE OLIUEIRA*}

Chris Tilly is Professor of Urban Planning at the University of California Los Angeles (UCLA). His research is focused on labor markets, inequalities, urban development and public policies aimed at better jobs. This interview with Tilly was conducted by Roberto Véras de Oliveira during his postdoctoral studies at UCLA, in Los Angeles, in 2016.

\section{Introduction}

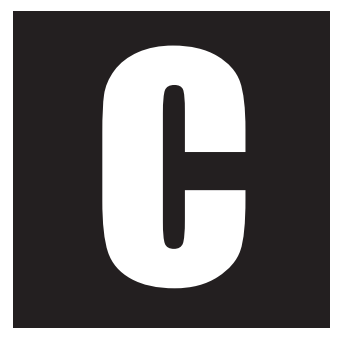

hris Tilly has a Ph.D. in Economics and Urban Studies and Planning from MIT, with the thesis entitled "Half a job: How U.S. firms use part-time employment". He was the director of UCLA's Institute for Research on Labor and Employment ${ }^{1}$ for eight years until June 2016.

Tilly comes from an intellectual family. His father, Charles Tilly, is among the most important contemporary American sociologists, and his mother, Louise Audino Tilly, historian, is author of an outstanding work on women's labor. From the beginning of his career, he has prioritized Labor and Employment studies, focusing on the USA and Latin America, thou-

* Federal University of Paraiba (UFPB), Brazil

1 See website: http://www.irle.ucla.edu/. 
gh also researching other parts of the world, and his approach is deeply interdisciplinary.

Throughout his over 30-years career as social researcher, our interviewee has produced numerous publications including journal articles and books, with emphasis on labor markets, inequality, urban development, public policies toward better jobs, social movements and collective action. One of the published books, "Work Under Capitalism", was coauthored with his father².

Alongside his successful career, Chris Tilly has developed a strong agenda as a social activist. His research has been mostly concerned with socially relevant issues brought up by advocacy groups, community organizations, and labor unions. In the last eight years, his personal trajectory was marked by the combination of both fields, and was carried out through the organic relationship between the IRLE and the UCLA Labor Center, a multidisciplinary research center dedicated to the study, teaching, and discussion on Labor and Employment, involving workers, students, researchers, and policymakers.

In this interview, Tilly explains about his trajectory, as well as about how he has incorporated a focus on informal and precarious work issues. $\mathrm{He}$, then, talks about the IRLE experience and its historical and current agendas on work and employment issues. The last part discusses the main trends in labor studies in the United States today, paying special attention to the topic of informal and precarious work.

Through these three approaches (Tilly's personal trajectory, that of IRLE, and US labor studies) we can grasp how do subjects such as work and employment, international migration and working conditions, gender, ethnicity-race and class, among others, relate to each other. In this regard, particularly interesting is the emergence of new forms of organiza-

${ }^{2}$ Westview Press, 1998. 
tion aimed at protecting informal and precarious workers, among which the workers' centers, which have worked through complementary and tense relationship with the unions. In contrast to a union agenda classically centered on white and stable American workers, the workers' centers are primarily concerned with undocumented Latin American migrants working under informal and precarious conditions.

\section{Tilly's academic and research trajectory}

Roberto Oliveira - Could you tell us how did you move toward Labor Studies in your academic and research experience? What were the main factors that drove you to this focus?

Chris Tilly - I will answer this by giving a little biography. My parents raised me with progressive views (for example, taking me to demonstrations for African-American rights and against the war in Vietnam), but I was not involved in an organization until I went to college. I went to college in the early 1970s, and I like to say that "we did not know then that the 1960s were over!" At college, I got very involved in the consumer boycott movement supporting the United Farm Workers (UFW) union, mainly Mexican-American farmworkers, led by Cesar Chávez.

In UFW support work, ideas like capitalism, the working class, and class struggle became much more concrete to me, and through that work as well as support for other labor movements I became very committed to economic justice, and deeply interested in labor. Although I had done a major in biochemistry, when I graduated I felt like the most important work was labor organizing.

So, I spent seven years doing labor organizing in hospitals. I learned an enormous amount, but unfortunately my comrades and I achieved very little success (it was a time when labor organizing was becoming 
much more difficult in the USA, for reasons I came to understand later, as a scholar). After seven years, I decided I could contribute more to the cause of labor as an academic, and I entered a doctoral program. But in my studies and my subsequent research, I continued to be passionately interested in labor. So, my interest in labor is probably shaped most of all by my life experiences.

RO - Why did informal and precarious work become so relevant in your research choices?

CT - From my days supporting the United Farm Workers, I was always interested in understanding and solving problems of inequality and workers who were worse off. My doctoral dissertation explored a "nonstandard" form of employment, part-time work. Since that time, all my major research projects have focused on various aspects of bad jobs and how to make them better. So, in some sense I have always studied precarious work, even before the term was invented.

But for most of my research career, I have looked at formal employment, not informal. My path to a strong interest in informal employment was also shaped by life experiences and political commitments. In 1973, in my third year of college, Chile's President Salvador Allende was overthrown by a coup d'état. I joined the movement in solidarity with the people of Chile, and that began a lifelong interest in Latin America. After decades of participating in Latin America solidarity movements and travel to various Latin American countries, I decided in 1992 that I had to bring Latin America, and labor in Latin America, into my research agenda. I began comparative research on retail jobs in Mexico and the United States. As I studied the retail sector in Mexico, it became obvious that I would need to take into account informal retail, and as I did, I became more interested in informal employment more generally. In 2011, working with a group of UCLA doctoral students, I organized a conference on "Labor in 
the Global South." We issued an open call for papers, and it became clear that some of the most interesting work on that topic was investigating new forms of informal worker organizing. Peter Evans (of University of California Berkeley and Brown University) and I discussed this, and decided to pull together researchers from around the world who were studying informal worker organizing in their countries. The group met in 2012, under the name Experiences Organizing Informal Workers, and the discussion was so exciting that this immediately became my main area of research.

RO - As researcher in Labor Studies, what in your view were the most important projects out of those in which you took part? Why?

CT - I think three projects have been particularly important. In one, with Philip Moss, I investigated barriers to employment for black workers in the USA, especially discrimination, skill requirements, and an ambiguous area of overlap between the two that we and others called "soft skills", such as motivation and ability to interact with others successfully. The research resulted in our co-authored book Stories Employers Tell: Race, Skill, and Hiring in America ${ }^{3}$. The project's analysis of the discriminatory impact of a growing employer emphasis on soft skills, and the evidence for widespread biased attitudes among employers, were useful contributions to the scholarly debate.

A second project, currently being completed by Françoise Carré and me, looks at variation in retail jobs both within the USA and around the world, comparing US retail jobs with those in five European countries and Mexico. Our main argument is that despite globalization, national institutions are alive and well and lead to different job quality in different countries. Retail jobs are overwhelmingly bad in the USA, but better elsewhere, because of different institutional ground rules; even Walmart acts quite

\footnotetext{
3 Russell Sage Foundation, 2001 (it was named a Notable Book by the Princeton University Industrial Relations Section).
} 
differently in different countries. We are completing a book provisionally titled: Where Bad Jobs Are Better: Why Retail Jobs Differ Across Countries and Companies.

Finally, I am very optimistic that the Experiences Organizing Informal Workers (EOIW) project will prove fruitful. My colleagues and I have only published some preliminary papers and the project is still in midstream, but I believe that finding ways for informal workers to mobilize and build power is the principal challenge faced by labor today. Furthermore, I believe that the many experiments currently underway in organizing informal workers, in spite of all their flaws and limits, are very promising and hold important lessons for the rest of the working class. It has been very exciting to work with collaborators like Rina Agarwala, Peter Evans, Enrique de la Garza, Sarah Mosoetsa, and Carlos Salas, and I look forward to further research findings ${ }^{4}$.

RO - How relevant have been the idea and practice of interdisciplinarity in your intellectual development and research experience?

CT - My main formation is as an economist, and I am very clear that my understanding of economics is deeper than of other disciplines such as sociology, and that I have certain "economic" habits of thought. At the same time, my formation and my approach to research have always been interdisciplinary. I did a dual doctorate in Economics and Urban Planning (itself an interdisciplinary field) at the Massachusetts Institute of Technology, and my studies included classes in Labor Relations, Political Science, and History. Though my first teaching job was in Economics, colleagues

\footnotetext{
${ }^{4}$ See about this Project: a) "Final Report: Informal Worker Organizing as a Strategy for Improving Subcontracted Work in the Textile and Apparel Industries of Brazil, South Africa, India and China". IRLE/UCLA, 2013 (available at: https://www.dol.gov/ilab/reports/pdf/ILAB-UCLA\%20Report\%20-\%20Final\%20Full\%20Report\%202013-09.pdf); and b) Carré, Françoise; Tilly, Chris; and Bonner, Christine. "International Informal Worker Organizations Transforming the world of unprotected work". Perspectives on Work, Vol. \# 16, 2014 (available at http://wiego.org/publications/international-informal-worker-organizationstransforming-world-unprotected-workperspecti).
} 
and I soon formed an interdisciplinary Policy and Planning department, and then an even more interdisciplinary Regional Economic and Social Development department (including scholars from economics, history, political science, psychology, and sociology). I now teach in an interdisciplinary Urban Planning department.

My research, as well, started out interdisciplinary and became more so. I collaborate far more with sociologists than economists. In my view, the dominant, orthodox approach of economics in the US pays far too little attention to the institutional context of markets, especially the labor market. This approach helps make problems methodologically tractable, and it is well suited to addressing some particular problems. However, I am most interested in questions of inequality, power, and collective action (whether the form of collective action is at the level of a class, a sector, or a workplace; and whether that action is in the sphere of the state, the economy, society, or cultural dimensions such as norms). To address these problems, I find an interdisciplinary research framework necessary.

RO - In your broader life experience, how did you manage to reconcile scholarly research with social activism? On the other hand, how did you reconcile social criticism with practical propositions to the social agents?

CT - As I have noted in bringing in parts of my biography, I have been an activist in one form or another since I was a child. In some cases, this does not connect directly with my research, and the connection is an indirect one, through a worldview that values social and economic justice, internationalism, and hearing the voices of those who are marginalized. In other cases, I have found ways to make the connection more direct. In these cases, the "arrows" go in both directions. Direction 1: I use my academic research and expertise to intervene in social activism. For decades, I have advised labor and social movement groups on the issues I am familiar with, spoken to the media about these topics, given testimony in legis- 
lative hearings and judicial processes, and made presentations to gatherings of activists as well as academic conferences and seminars. Direction 2: Social activism informs my academic research topics and the substantive questions I explore. Concern about the spread of punitive welfare "reforms" in the USA led Randy Albelda and me to do the research that resulted in the book Class Ceilings and Bottomless Pits ${ }^{5}$, and conversations with audiences around the state of Massachusetts helped us shape our framing. Meetings with "horizontalist" activists in four Latin American countries spurred me to write a series of articles about what Marie Kennedy and I call Latin America's "third left". My growing awareness of informal worker activism in Los Angeles, across the USA, and around the world drove me to launch the EOIW research network. Informed by this continuing set of learning experiences, I often include activists as presenters in academic events as a source of ideas and to stimulate broader dialogue.

RO - How did your path cross with the IRLE/UCLA?

$\mathrm{CT}$ - There was a national search for a new director for the Institute in 2007-2008. I was immediately interested, because of the IRLE's deep integration of research with community outreach, and of scholars with practitioners. I also knew that the Los Angeles labor movement was the most innovative in the USA, and was linking traditional job quality issues to struggles for immigrant rights, access to jobs for communities of color, and environmental sustainability. So, I applied for the job, and was fortunate enough to be hired. I worked as director from 2008-16; I now have stepped down from that position and become a regular professor and researcher at UCLA.

${ }_{5}^{5}$ South End Press, 1997. 


\section{IRLE's institutional and research trajectory}

RO - Could you briefly present us the IRLE's history, primary mission, and sort of activities that have been prioritized along the time?

CT - The UCLA Institute for Research on Labor and Employment was created in 1946 by the California Legislature, along with a sister IRLE at the University of California Berkeley. It was born out of the new US concern about industrial relations that emerged with the militant and very successful labor movements of the 1930s, and then the institutionalization of a field and profession of industrial relations during World War II, when the US government hired labor experts to work with unions and management to avert strikes and keep production humming during the war.

The IRLE has followed a changing path in two ways. First, at times its focus has shifted more toward scholarly activities, at times less in that direction-for example, in 1964 unions in California, unhappy that the IRLEs at UCLA and Berkeley had become too academic, pressed for the creation of affiliated Labor Centers, which would carry out more work outside the academy. The Labor Centers created then continue to function as part of the IRLEs today. Second, over the last 15 years or so, there have been concerted political attacks from conservatives and anti-union forces aimed at eliminating the IRLEs. In fact, three weeks after I started my job, the then-Governor of California vetoed all funds for both IRLEs. Fortunately, we were able to secure funds to continue operating, but this was only one of a series of very serious challenges to the IRLEs' continued existence.

Despite this fluctuating path, the UCLA IRLE (and the Berkeley one) has continued to function, and has always included both scholarly activities and more practical ones oriented to outreach to communities, workplaces, and unions along with other organizations serving working people. 
RO - In institutional terms, how is IRLE structured and how does it work?

CT - The IRLE is a unit of the University, and reports to the Dean of Social Sciences. The IRLE is the overall umbrella organization, and there are four subunits with it. The largest is the Labor Center (Center for Labor Research and Education)6, which does community outreach, popular education, applied research, and technical assistance. Next comes the Labor Occupational Safety and Health Program (LOSH)7, which conducts training programs on worker health and safety (for workers, worker organizations, health professionals, and employers) and carries out research and technical assistance on these topics. There is also an Academic Unit that organizes colloquia and conferences, hosts research projects and visiting scholars, provides small research grants, and facilitates communication and collaboration with scholars on other campuses and around the world; the Academic Unit and the Labor Center jointly sponsor a Minor in Labor and Workplace Studies, and the IRLE is currently mobilizing to upgrade this to a Major. The smallest subunit is the Human Resource Round Table (HARRT)8, a networking and continuing education program for top Human Resources officials in a variety of employers. All the subunits function relatively independently, but all are accountable to the IRLE and there are sometimes cross-subunit collaborations like the Minor.

RO - Has IRLE been able to articulate different areas and departments at UCLA in order to support its project?

CT - The IRLE has strong links with UCLA programs in the Social Sciences, the School of Public Affairs, the School of Law, the School of Public Health, and the International Institute. There are also connections with the School of Education, and with a range of other research centers, especially the Ethnic Studies centers and the Center for the Study of

\footnotetext{
${ }^{6}$ See: http://www.labor.ucla.edu/.

7 See: http://losh.ucla.edu/.

${ }^{8}$ See: https://harrt.ucla.edu/about-us/.
} 
Women. IRLE colloquia and conferences are invariably cosponsored with other UCLA units.

RO - On the other hand, how has IRLE been able to combine scholarly studies and practical intervention actions? In this regard, what have been the role of the UCLA Labor Center?

CT - IRLE's dual mission as a "think and do tank" permeates all its activities. The IRLE's more scholarly research often bears on public policy or social movement strategy. The Labor Center's outreach is often informed by action research. In Labor Studies Minor classes, undergraduate students often carry out field-based research and service learning in conjunction with community-based and labor organizations. Still, the Labor Center, LOSH, and HARRT do more at the "do" end of the spectrum, and the Academic Unit does more at the "think" end. The resulting tension is not always easy to manage, and can lead to conflicts over priorities and resources. But ultimately it is a creative tension that pushes each of the units to integrate thought and action in new ways that make work better. One innovation has been to create IRLE Dialogues that bring together UCLA researchers in varied positions (professor, postgraduate students, visiting scholars) along with practitioners to discuss timely issues.

RO - In this regard, could you talk about the IRLE's participation on the minimum wage local campaign that resulted in the official adoption in Los Angeles, in 2015, of a minimum wage that rose to $\$ 15 /$ hour?

CT - Issues of low-wage work have been a major focus of the IRLE throughout my term as IRLE Director, and that of my predecessor, Professor Ruth Milkman (now at the City University of New York). Ruth conducted extensive research on labor organizing among low-wage workers, and spearheaded a study of wage theft in Los Angeles that showed that many low-wage workers were not paid the minimum wage or overtime premium. I co-edited two related books, The Gloves-Off Economy: Labor 
Standards at the Bottom of America's Labor Market ${ }^{9}$ and Are Bad Jobs Inevitable? ${ }^{10}$, and organized related research and scholarly dialogue. Labor Center researchers and outreach coordinators continued building our knowledge base on wage theft, and participated actively in public dialogues on the subject.

When Los Angeles labor activists proposed a \$15/hour minimum wage (following similar laws in Seattle and San Francisco), both the Labor Center and the IRLE Academic Unit joined with the Los Angeles Economic Roundtable to produce a report assessing the likely impact of this higher minimum. We helped make the case for a higher minimum wage by showing that positive results were likely, and our ongoing work on wage theft helped to motivate the City of Los Angeles's creation of a new enforcement agency to ensure that the $\$ 15$ minimum wage actually gets paid. We are proud that we contributed to these historic outcomes. Currently, the IRLE is collaborating with the UCLA North American Integration and Development Center to help smaller Southern California municipalities forecast the effects of raising their own minimum wages to $\$ 15$, in order to help them to decide whether to follow Los Angeles's example.

RO - What have been, historically, the main research topics conducted by IRLE staff? As regards to IRLE's current research agenda, has something changed in terms of priority activities, thematic focus or approach perspective?

CT - The IRLE's research agenda has always centered on labor, work, and working people. However, the focus has changed over time, reflecting the issues that commanded attention in the outside world, as well as differing interests of IRLE and Labor Center leaders. For example, in the 1960s, as the Civil Rights Movement for the rights of African Americans

9 Cornell University Press, 2008 (co-edited with Annette Bernhardt, Heather Boushey, and Laura Dresser).

${ }^{10}$ Palgrave, 2012 (co-edited With Chris Warhurst, Françoise Carré and Patricia Findlay). 
was having a huge impact in the USA, IRLE researchers began to look more at issues of racism and racial stratification in the workplace. From the 1990s forward, with historically high levels of immigration to the USA, especially from Latin America, IRLE and especially the Labor Center have developed initiatives centered on immigrant integration. In the last few years, as the Black Lives Matter movement has exploded, and has reminded us of how policing and the criminal justice system build in inequalities by race, ethnicity, and class, the IRLE has supported more research looking at how these systems affect working people.

As I mentioned before, my predecessor, Ruth Milkman, along with Kent Wong, Director of the Labor Center, established a strong emphasis on issues of low-wage work. As Director, I continued this emphasis, but I also increased the focus on international networking and comparisons. For example, the first IRLE conference I organized looked at work and workers in China, Mexico, and the USA; subsequent conferences discussed labor in the global South and international comparisons of migration and workforce diversity (though we also organized conferences on more US-focused topics). IRLE also helped organize a recent global conference on Precarious Work that took place in Seattle ${ }^{11}$, and I have participated in many other global gatherings including congresses of the Global Labor University, the International Sociological Association, and the Latin American Labor Sociology Association (ALAST). During my tenure, we greatly increased the presence of visiting scholars from abroad. And my own main research projects during this time were comparative: comparing retail jobs around the world, and comparing informal worker organizing in varied countries. Overall, the IRLE's main programmatic themes when I was Director were Improving Low-Wage Work, Immigrant Integration, and Global Flows and Networks. However, the IRLE now has a new Di-

${ }_{11}$ On this topic, see: http://www.irle.ucla.edu/events/PrecariousWork.php. 
rector, Professor Abel Valenzuela, and he will define his own particular thematic focus.

\section{Current trends in labor studies in the US}

RO - In your point of view, has the Labor Studies agenda changed lately in the US? Could it be said that themes like informality and precariousness have gained increasing relevance within the American Labor Studies?

CT - I would point to three changes in the US Labor Studies agenda: a long run change (over the last 40 years), a medium-term change, and a more recent change. Over the long run, unions have grown weaker in the United States (falling from one-third of the private sector workforce to about one-sixteenth, for a variety of reasons), and correspondingly, attention to work and labor relations has declined. Whereas several decades ago most management schools had departments of industrial relations or labor relations, today they are uncommon, and the same decline can be traced across the social sciences. So, Labor Studies has become a smaller, less powerful, and more isolated field of inquiry in the USA.

In the middle run (over the last 20 years), US labor scholars have been greatly influenced by the process of globalization. Much more research by US labor scholars now studies work in other countries, or compares work and workers across countries (as my own does).

In the short run (over the last 10 years, and continuing to increase), there is indeed a boom in attention to precarious and informal work. This attention is driven by a perception that work has tended to become more precarious since the rise of neoliberalism, and that the 2008-10 recession intensified this trend. The conference on Precarious Work that IRLE and others organized got an enthusiastic response, and I am aware of numerous recent and upcoming journal special issues focusing on precarity and 
informality. This focus is much-needed, since in my view finding ways to organize and build the strength of informal worker movements is today the principal challenge facing the labor movement and those who support the interest of working people, both in the United States and across the world.

RO - Is interdisciplinarity now stronger than before within the current American Labor Studies? Has there been effective advancement in that area? Or does it remain a big challenge once more highlighted but which does not present effective progress yet?

CT - The USA has always had a strong streak of intellectual pragmatism, which has made space for interdisciplinary approaches. Fields like industrial relations (now more often called labor relations, or even "work and employment") have been interdisciplinary from their origins. Similarly, labor educators who run "extension" programs with classes for trade unionists and other workers, draw from multiple disciplines. Most of the leading research centers on Labor Studies across the USA, including the UCLA IRLE, are deeply interdisciplinary. At the same time, the traditional disciplines' claims of "turf" and their practice of drawing boundaries remain very strong. I see advances toward widespread interdisciplinary dialogue and collaboration as quite limited.

RO - Finally, we would like to hear your opinion on some questions that are maybe among the most current challenges to Labor Studies in US. First of all, for you, what are the most important factors that led to the increase of informal and precarious work in the US in the last decades?

CT - I see influences from two main factors. On one side, employers have tried to cheapen labor, in many cases "fissuring" workers from each other via subcontracting chains, franchising, the use of temporary workers, and other devices that divide workers into different statuses - most recently including the hiring of people as "independent contractors" through online platforms such as Uber. Many employers have also actively op- 
posed unions, trying to keep them out or to shed them if they are present. In general employers seek to decrease their obligations and commitments to workers, moving away from long-term employment, opportunities for advancement, and employer-provided fringe benefits (except for a privileged few workers whose skills are in high demand).

On the other side, the state - including national, state, and local governments - has pursued a set of neoliberal policies. These include "flexibilization" of labor through decreased enforcement of labor standards; shrinking the welfare state directed to workers; government withdrawal of support or in some cases attacks on unions; deregulation of business; and "free trade" agreements that defend capital's interests but not labor's.

Related to neoliberalism but somewhat distinct, the United States is pursuing public policies that generate large labor supplies who have few alternatives or protections. A "semi-liberal" immigration regime tacitly accepted large-scale migration in response to employers' stated needs, but consigns undocumented migrants to a shadowy existence, subject to deportation if they displease an employer. Incarceration of millions of people generates a large flow of ex-offenders seeking work but facing huge stigma with few job search resources or skills. Scaling back of welfare programs pushes into the workforce many facing barriers to work (young children, disabilities, lack of basic skills), who would previously had social safety net programs as an option.

Similar processes are at work in economics and politics in many of the other countries of the world.

RO - In this regard, what weight should be given to phenomena like deindustrialization, business strategies of outsourcing, displacement of jobs from manufacturing sector to service sector, growing immigration, greatest influence of neoliberal ideology on governments and policy makers, and others? 
CT - I have spoken to most of this list, but I did not include deindustrialization or shifts from manufacturing to services, for a reason. If there were strong protective institutions in place — laws that facilitate unionization, a minimum wage that is a "living wage", holding businesses responsible for workers in their supply chain or whom they hire through "third-party" arrangements such as temporary help agencies or franchising - then these would also apply to sectors where jobs are growing. The problem is not driven by a shift from one sector to another, but by new employer strategies to cheapen labor, and new government policies that aid that drive rather than limiting it.

RO - Could it be said that the Labor Studies in the US have been able to reveal consistent evidences of organizational experience by informal and precarious workers themselves? On the other hand, have such sort of studies pointed out public policy experiences that have been able to improve the social security of informal and precarious workers?

CT - Labor Studies in the United States has definitely shown important examples of organizing by informal and precarious workers. The work of Ruth Milkman, Nik Theodore, Eileen Boris, Dorian Warren, Janice Fine, Abel Valenzuela, and many others points to varied organizing initiatives. It is important to underline that though this organizing marks an important advance, it is only reaching and involving a very small percentage of informal and precarious workers. Still, there are some lessons. I and others have pointed to the fact that rather than collective bargaining with employers, public policy has been the most important arena for (limited) victories - and political alliances with other actors, including unions, has been essential for these victories. Successes including higher local and state minimum wages, legislation to detect and punish wage theft, laws mandating paid sick days and advanced notice of work schedule, starting to hold businesses responsible for the labor violations by their subcontrac- 
tors, and in some cases laws barring license renewals to businesses that have a track record of illegal labor practices, or directing public purchasing based in part on businesses' behavior as employers. Some successes involve the passage of a law, or winning a lawsuit, that targets an individual sector or even a single employer — for example, Domestic Workers' Bills of Rights passed at the state level, court decisions affirming the legality of day laborers soliciting work in public spaces, or wage theft judgments against restaurants that result in back pay to workers and, in some cases, mandate certain employer practices going forward as well. All of these "wins" are more common in politically left-leaning cities and states.

RO - Could you speak a little bit about the experience of the labor centers in the US and about their connections with trade unions? What gains and limitations have resulted from this kind of interaction in terms of advance in a social rights agenda?

CT - In the US, worker centers have sprung up in industries where forming unions is extremely difficult or impossible: domestic work, day labor construction, restaurant work, much of the retail sector, and so on. These worker centers integrate elements of unions, NGOs, advocacy organizations, and mutual support networks to serve workers, especially migrants from other countries. Some define their focus by sector; others are organized more along ethnic/national lines than sectoral ones. They have had important impacts in raising awareness about these workers and jobs, and in winning public policy victories. However, they have not yet been able to build mass memberships.

Individual worker centers are localized, but some of them have formed national networks, notably the National Domestic Workers Alliance (NDWA), the National Day Laborers' Organizing Network (NDLON), and the Restaurant Opportunities Centers-United (ROC-U). There is also a national "network of networks", the United Workers Congress, that in- 
cludes these networks and others. Within a particular city or metropolitan area, worker centers form alliances with each other and with unions, faith-based organizations, and other progressive groups. At the national level, NDWA and NDLON have also established formal alliances with the AFL-CIO, the main union federation in the USA, and NDLON has built a particular collaboration with the Laborers' International Union to organize construction workers. In these alliances, as in worker centers' work in localities, the biggest successes have been in raising public awareness and achieving public policy reforms, not recruiting members nor engaging in collective bargaining.

RO - How could the Labor Studies on informal and precarious work be better associated with themes like migration, racism and ethnicity, and gender? Have the empirical researches advanced in improving the approach on these associations? Have the efforts of (re)conceptualization progressed in these approaches?

CT - In the USA, and for that matter around the world, there is clear evidence that women, racially or ethnically marginalized groups, and migrants are more likely to end up in precarious or informal work. (In other countries, such as China or India, the main relevant axis of migration is cross-regional within the country, rather than cross-national.) This is nothing new - these groups have long been concentrated in worse jobs, in the "secondary labor market," and so on, given their lesser access to economic and political power and privilege. But useful analysis must move beyond this general observation to understand how gender, race and ethnicity, and migration status help structure informal precarious work, and more generally how these categories structure class, and vice versa. There has been much attention, in US Labor Studies, to race and gender, so some of the key analytical tools are available. Still, we are really just at the beginning of understanding how such socially constructed differences 
interact with informality and precarity. For example: How do precarious and informal work generate different opportunities and experiences for men and women, given gender segregation and discrimination? How do ethnic and/or migrant brokerage and chain migration processes condition workers' access to various kinds of work? How do race, ethnicity, migrant status, and gender shape the ways that informal and precarious workers view their work, resist, mobilize, form organizations, and undertake repertoires of strategies and tactics? And so on. This is a very fruitful area for investigation, and more research is underway.

RO - Having into account the current tendency towards work informalization and precarization that reaches most sectors of [US's]economy, what does remain distinct from and what is now closer to the situation of Latin American countries? Could it be said that so adverse conditions, both in the South and the North, have led to more similar realities in terms of work and its connection with themes like unionism, development, citizenship, and democracy?

CT - It seems safe to say that the direction of evolution of work in the United States and Latin America, and indeed in most of the global North and global South, has been similar (though for close to ten years there was an important "Brazilian exception", which now seems to have ended due to the "constitutional coup" that ousted Dilma). And each region can learn from the other, a subject to which I will return afterwards. However, it is important to keep in mind three caveats.

First, the similar direction of evolution across the Americas is not a new development. The large Latin American countries didn't industrialize as early as the USA, but they did industrialize. As the United States went through the New Deal reforms of the 1930s and functioned on "weak" social democratic principles up to the 1970s, many of the countries of Latin America saw varieties of populist, corporatist, and/or developmen- 
tal parties and states that pursued similar policies relative to labor. The neoliberal turn originated in the United States, but was most rapidly and dramatically implemented in Latin America, notably in Chile after 1973 — resulting in growing inequality and the precaritization and informalization of labor.

Second, though the direction of evolution is similar, the absolute status of workers differs greatly between North and South. Majorities of the workforce in many Latin American countries are informal according to standard definitions, and the USA is not close to that level yet. More of the population in Latin America is destitute and desperate, making informal work a matter of survival for large numbers.

Third, the political response to precaritization has been different in the two regions. In Latin America, growth of informal and precarious work was one of the stimuli to the "pink tide" of center-left, left populist, and social democratic governments - a tide that now seems to be receding. Progressive Latin American governments expanded downward income redistribution, taking advantage of the "bonus" from the commodity boom that prevailed through much of the 2000s. Governments tolerated and in some cases supported (some) social movements for economic and racial/ ethnic justice, and in many cases boosted labor standards enforcement. The Lula and Dilma Workers Party governments in Brazil were exceptionally active in combining redistribution, targeted policies to develop manufacturing and commercial agriculture, stronger labor law enforcement, and tacit support for unions, leading to more equal incomes, decreased informality, and increased union density - but with the end of the commodity boom, growing economic distress, and the "constitutional coup", one cannot be optimistic that these trends will continue. The political response across Latin America also includes political mobilizations from below by unions and social movements - though in many cases populist 
governments successfully contained, channeled, or selectively supported movements so as to block strong, independent grassroots movements.

Meanwhile, in the United States, eight years of Obama government with fierce opposition from the Republican party in the legislative branch have yielded "neoliberalism lite", and most significant economic justice and worker rights victories have been won only at the local and state level (as mentioned above), not at the national level. In terms of bottom-up responses to precaritization, the worker center movement and some particularly active unions have been scrappy and innovative fighters, but they have remained small compared to the scale of the problems, and have had limited effects. Perhaps the greatest source of optimism is the so-called "Millennial" generation (born roughly 1977-1994), for whom the experience of the deep recession of 2008-10 has sparked very progressive ideas on economic justice and a variety of other issues. The Millennials, the largest generation ever born in the USA, were central to the Occupy Wall Street campaign and the surprisingly successful left populist campaign of Bernie Sanders for president, as well as leading other movements such as the powerful Black Lives Matter movement. As they become a more important presence in the electorate, in the workforce, and in the range of US institutions, one can hope for more progressive responses to the current crisis of work. But this potential remains to be seen.

Because the countries of the global South have been wrestling with large-scale precarious and informal work much longer than their counterparts in the North, labor movements and policy advocates in the USA, Europe, and Japan, have much to learn from Southern policy and movement-building experiences. For example, India's Self-Employed Women's Association (SEWA), in existence for more than four decades, is arguably the most successful national network of informal workers organizations (among other things, it is India's largest union federation!), and has pione- 
ered organizational experiments including cooperatives and associations of informal workers, and has knit them together into an organizational with local, regional, and national power. Brazil's Solidarity Economy network, similarly, is the most advanced in the world. And there are important global networks of informal worker organizations, including the International Domestic Workers Federation (based in Hong Kong), StreetNet (street vendors, based in South Africa), and HomeNet (home-based workers, based in India) - all of which originated in the global South, have shared lessons across the South, and now are increasingly including Northern organizations and advocates in the dialogue.

RO - Please feel free to make your final considerations, maybe indicating how do you see the future of work and of the Labor Studies.

CT - The leading scholars of labor have always been motivated by having a real impact in the world of work, whether the goal was to obtain worker consent and effort (as in the Human Resources field), to help labor and management find win-win compromises (the origins of the field of Industrial Relations), or to aid worker dissent and organizing (more left strains in Labor Studies). The fortunes of Labor Studies have consequently mirrored the fortunes of labor in the world. For each of the goals espoused by different currents within Labor Studies, neoliberalism's devaluation of worker needs and voices has created more of an uphill battle. For those of us on the left of Labor Studies, it is the steepest uphill battle of all. But as Peter Evans and I argued in our recent essay on "The Future of Work" (in the Sage Handbook of Work and Employment, 2015), there are "green shoots" that suggest the possibility of a better future for work, and that also promise a better future for Labor Studies. These include some of the grassroots movements I have mentioned in this interview, the growth and consolidation of Solidarity Economy initiatives and networks in much of the world, the persistence of progressive economic and labor reforms (on 
the part of some governments) even in the darkest days of neoliberal hegemony, and the continuing information and communications technology revolution that democratizes access to knowledge, and challenges the grip of capital and ruling elites on the means of production - foremost among which is knowledge itself in this information era. Today, in the United States, in Latin America, and around the world, there is a modest virtuous circle linking intellectual innovation in Labor Studies with practical innovation in organizing, advocacy, and public policy. To the extent we can expand this small foothold, there is the potential to open the door for very exciting advances in Labor Studies, and for labor as a subject in the world.

Roberto Véras de Oliveira is Associate Professor at the Federal University of Paraíba (UFPB), in both the Department of Social Sciences and the Graduate Program of Sociology.

$\sum$ roberto.veras.2002@gmail.com

Received: 02.20.2017

Accepted: 04.25.2017 